Britain's armed forces and amphibious operations in peace and war 1919-1939: A Gallipoli Curse?

Matthew Heaslip

School of Area Studies, History, Politics, and Literature, University of Portsmouth, Portsmouth, UK

matthew.heaslip@port.ac.uk

15 Henham Gardens, East Peckham, Tonbridge, Kent, TN12 5PD, UK.

+44 (0)77077 64355

www.linkedin.com/in/matt-j-heaslip 


\title{
Britain's armed forces and amphibious operations in peace and war 1919-39: A Gallipoli Curse?
}

\begin{abstract}
Gallipoli left a lasting impression upon both the countries that participated and many that did not. It has been argued that the campaign negatively influenced Britain's interwar amphibious preparations. Instead, this article will show that Britain's armed forces were largely unaffected by such memories, and maintained their relative global standing in theory, equipment, and training exercises for landing operations. The paper also highlights the role of amphibious warfare in fighting the many 'little wars of Empire' during the period.
\end{abstract}

Keywords: Gallipoli; amphibious operations; naval fleets; military operations; imperial policing; peacetime.

Gallipoli stands out as a First World War campaign that left significant and lasting marks upon the collective memories of the nations involved. This was particularly true of armed forces worldwide, many of whom studied the campaign in order to gain insights into the feasibility of future combined or amphibious operations. Appreciating Gallipoli's impact upon Britain's armed forces provides vital perspective on the military significance of the campaign itself and the failure's relationship with later events. Early mistakes made during Britain's involvement in the Second World War, for example, have been attributed to Gallipoli's lasting influence, both in terms of inadequate amphibious preparations and Winston Churchill's leadership. ${ }^{1}$ Interwar amphibious debates also provide valuable insights into how imperial policing challenges were

${ }^{1}$ C.M. Bell, Churchill and the Dardanelles (Oxford: Oxford UP, 2017), 304-356; J. Kiszely, Anatomy of a Campaign: The British Fiasco in Norway, 1940 (Cambridge: Cambridge UP, 2017), 287-288, D. MacGregor, 'The Use, Misuse, and Non-Use of History: The Royal Navy and the Operational Lessons of the First World War' Journal of Military History 56/4 (1992), 609-616. 
approached and Britain's defence priorities evolved. This article will review many of the existing assumptions about interwar amphibious developments and better place the events within the context of the period.

Our historical understanding of Britain's interwar amphibious studies has always been tied closely to Gallipoli. Both the wartime Dardanelles Commission and subsequent post-war review by the Mitchell Committee attempted, but largely failed, to assess what had gone wrong during the campaign, setting the scene for what followed. Gerald Ellisons' 1926 account launched straight into the resulting public debate, focusing on the top-level strategic decisions behind Gallipoli, although he did mention a resurrected plan in 1916 to land troops near Iskenderun. ${ }^{2}$ Basil Liddell-Hart's subsequent musings became entwined with those arguments - over whether Gallipoli was destined for disaster. A controversial military theorist and strong proponent of the indirect approach, Liddell-Hart's work heavily influenced later debate of the topic. He argued that interwar exercises merely refought the campaign in an attempt to exorcise its ghosts. ${ }^{3}$ This formed a common theme in histories written up until the late 1990s, that deep scars left by Gallipoli effectively closed the door on future amphibious operations. ${ }^{4}$ Bernard Fergusson stated this most clearly with 'on the whole people

${ }^{2}$ G. Ellison, The Perils of Amateur Strategy (London: Longman, 1926), xxi-23.

${ }^{3}$ B. Liddell Hart, When Britain Goes to War (London: Faber and Faber, 1935), 239-255; B. Liddell Hart, The Liddell Hart Memoirs Vol. 1 (London: Cassell, 1965), 281-306.

${ }^{4}$ A.J. Marder, From the Dardanelles to Oran: Studies of the Royal Navy in War and Peace 1915-1940 (London: Oxford UP, 1974), 52; J. Thompson, The Royal Marines: From Sea Soldiers to a Special Force (London: Pan, 2001), 227; A. Whitehouse, Amphibious Operations (London: Frederick Muller, 1963), 178-181. 
remembered the carnage on the beaches to the exclusion of all else' to summarise how Gallipoli affected interwar amphibious consideration. ${ }^{5}$ The consensus was that the campaign was not just seen as a defeat, but as something more, a major shift in warfare resulting from the emergence of new weapons and tactics. In essence, that it was no longer seen as a practical venture to deploy military force by ship into hostile territory, without pre-secured landing sites.

Early attempts to offer contrasting views raised interesting points, but lacked sufficient supporting evidence. ${ }^{6}$ David MacGregor's 1992 counter-argument represented a notable shift, stating that Gallipoli 'did not discredit amphibious warfare, it distorted it'. Nonetheless, he believed that a 'Gallipoli Curse', in his words, had afflicted British interwar military planners. ${ }^{7}$ In recent years, Richard Harding, Joseph Moretz, and Ian Speller have taken further steps towards revising the established narrative. ${ }^{8}$ They have shown that the period was not completely devoid of amphibious

${ }^{5}$ B. Fergusson, The Watery Maze (London: Collins, 1961), 35.

${ }^{6}$ K. Clifford, Amphibious Warfare Development in Britain and America from 1920-1940 (NY: Edgewood, 1983); G. Till, 'Hitting the beach: the amphibious experience', in eds. J. Bourne, P. Liddle, and I. Whitehead, The Great World War 1914-45: 1. Lightning Strikes Twice (London: HarperCollins, 2000); G. Till, 'Amphibious Warfare and the British', in T. Farrell, M.J. Grove, G. Till, Amphibious Operations: A Collection of Papers (Camberley: SCSI, 1997), 16-19.

${ }^{7}$ MacGregor, ‘Use, Misuse and Non-Use’, 603-616.

${ }^{8}$ R. Harding, 'Amphibious Warfare 1930-1939', in ed. R. Harding, The Royal Navy, 1930-2000 Innovation and Defence, (London: Frank Cass, 2005), 42-64; J. Moretz, Thinking Wisely, Planning Boldly: The Higher Education and Training of Royal Navy Officers, 1919-39, 
development, as was portrayed in the formative post-war accounts.

This paper will review Britain's interwar preparations for amphibious landings, both in wartime and as a means of imperial policing. Going beyond existing accounts, it will argue that Britain's armed forces made significant strides and were no worse prepared than their international peers throughout most of the interwar period. Developments in theory and operational planning are first explored, before a global comparison of specialist amphibious equipment and doctrine. These will show that Britain's efforts were generally proportionate and logical, when viewed in context. This paper then highlights combined operations' vital role in maintaining and defending the British Empire, as a means of last resort for restoring control over far-flung territories. Moreover, that imperial policing often involved complicated and risky operations that were akin to wartime raids. In summary, this paper emphasises Gallipoli’s limited influence over interwar developments and provides greater context around global developments in amphibious capabilities during the period.

\section{Studying the past}

To begin, we explore Bernard Fergusson and Brian Schofield's suggestions that British officers felt amphibious doctrine and capabilities needed to be improved, but with both dismissing any achievements made prior to 1936 . They argued that such efforts were consistently hamstrung by financial restrictions imposed by successive

(Solihull, Helion, 2014), 326; I. Speller, 'In the Shadow of Gallipoli? Amphibious Warfare in the Inter-War Period', in ed. J. Macleod, Gallipoli: Making History, (London: Routledge, 2004). 
British governments. ${ }^{9}$ Arthur Marder added weight to those views when colourfully describing the interwar studies and resulting manuals, as having consumed a lot of ink and 'much gin', but achieving little. ${ }^{10}$ Despite minimal supporting evidence for that assertion Marder has been restated frequently, including recently in Richard Brook's history of the Royal Marines. ${ }^{11}$ Marder's key assessment is misleading, however, as those often detailed theoretical discussions led to practical exercises that were intended to, and did, facilitate further serious debate about combined operations.

Exploring the interwar amphibious studies, a good portion of the officers involved approached the exercises in a professional manner, with a forward-looking frame of mind. This began with the 1919 technical assessment of the Gallipoli campaign, which emphasised the pressing requirement for Britain to revolutionise its approach to landing operations. ${ }^{12}$ Gallipoli was just one of many First World War campaigns that demonstrated how warfare had evolved, as a result of which new approaches were actively sought to overcome the latest challenges.

As early as 1920, a potential fresh assault against Turkey was considered in the event of a renewed conflict. The initial report was produced by the Army staff college at Camberley and later circulated to the other services. The officers involved treated a potential landing as a serious possibility. Indeed, the language used conveyed a desire to

\footnotetext{
${ }^{9}$ B.B. Schofield, British Sea Power (London: Batsford, 1967), 199-200; Fergusson, Watery Maze, 37.

${ }^{10}$ Marder, Dardanelles to Oran, 52.

${ }^{11}$ R. Brooks, The Royal Marines: 1664 to the Present (London: Constable, 2002), 252-254.

${ }^{12}$ MacGregor, 'Use, Misuse and Non-Use', 607.
} 
do the job properly the second time around, even implying a thirst for revenge. ${ }^{13}$ The resulting plans went into considerable depth, with a wide selection of intelligence reports about target regions and the condition of Turkey's armed forces. This included detailed illustrations of potential landings sites and the routes inland from them. The file also contains a note from early in the process, outlining that an alternative exercise exploring an assault on the Panama Canal was proposed, but quickly rejected. The diplomatic risk of assembling detailed plans against American interests was too great. Comprehensive research and carefully considered diplomatic risks are not in-keeping with the picture of gin-fuelled armchair debates painted by Marder.

Nor do these studies show much evidence of having been affected by antiintellectualist attitudes, whereby well-connected, gentlemanly naval officers were favoured over those of greater technical ability. ${ }^{14}$ A rare exception, a 1925 Greenwich Staff College exercise considering a landing near Tripoli, does show signs that the authors were not the most technically able. Vague assumptions about identifying the correct landing beaches before sunrise, for example, were highlighted as naïve by the nameless senior officer reviewing the paper. Nonetheless, the plans they produced required significant effort and, crucially, still showed far greater understanding of the difficulties involved in amphibious operations than was displayed at Gallipoli and in

${ }^{13}$ Kew, UK, The National Archives (TNA), War Office (WO) 106/64, Plans, intelligence reports, and staff exercises for landing on the Anatolian Coast, 1920.

${ }^{14}$ A.J. Marder, 'The Influence of History on Sea Power: The Royal Navy and the Lessons of 1914-1918' Pacific Historical Review 41/4, (1972), 439; C.M. Bell, 'The King's English and the Security of the Empire: Class, Social Mobility, and Democratization in the British Naval Officer Corps, 1918-1939’ Journal of British Studies 48/3 (2009), 699. 
pre-1918 staff papers. ${ }^{15}$

Here it is vital to differentiate between the intended audiences for those studies. Assessments by officers working on secret contingency plans, were of a very different tone to those intended for public dissemination. Military theorists weighed decisions and losses against intended aims, in a fairly objective manner, considering the potential likelihood of success. In contrast, the public were generally unable to separate between what had been conceived, what occurred, and what could have been, driven instead by a desire to know what had gone wrong. ${ }^{16}$ Over 50,000 allied soldiers had perished during a campaign that was an unequivocal failure, and their friends, relatives, and counterparts wanted to know why. Public accounts therefore focused upon attributing fault, to explain the disaster, some of which could be deflected by assertions that Gallipoli marked a turning point in how warfare could be conducted. ${ }^{17}$ That process was exacerbated by Winston Churchill, Ian Hamilton, and other prominent individuals involved in the campaign, who fought running literary battles to push blame for the failure onto others. ${ }^{18}$ This includes authors such as Ellison, who sought to exonerate the Army by attributing guilt to those politicians who launched the strategy. Those accounts clouded the waters of what actually happened, both for the public, and in later academic

${ }^{15}$ Greenwich, UK, National Maritime Museum (NMM), Troubridge (TRO) 401/5, Staff College Scheme 33, 19 Feb. 1925; T. Travers, Gallipoli 1915, (Stroud: History Press, 2009).

${ }^{16}$ D.W. Lloyd, Battlefield Tourism: Pilgrimage and the Commemoration of the Great War in Britain, Australia and Canada 1919-1939 (Oxford: Berg, 1998), 97-99.

${ }^{17}$ Marder, Dardanelles to Oran, 34.

${ }^{18}$ Bell, Churchill and the Dardanelles, 304-356. 
discourse. ${ }^{19}$

A second-tier military nation, equipped with a moderate supply of modern weaponry, had comprehensively halted an expedition into which two major global powers and their allies had poured men and materiel. Moreover, Gallipoli highlighted how lethal machineguns were over open beaches and the effectiveness of submarines against major warships in coastal zones. Detailed theoretical discussions and plans for amphibious operations were important, but overcoming those new challenges required serious tangible preparations. In this department, Schofield and Fergusson's argument that little happened before 1936, due to financial restrictions, encompassed equipment as well as theory. ${ }^{20}$ Their accounts complemented contemporary assessments of interwar defence expenditure, although questions have since been raised about the scale of cuts made to Britain's peacetime defence budget. ${ }^{21}$ Beginning with Allan Millett and continued by Harding, that financial centric argument has been tempered by considering other factors, including colonial service requirements. ${ }^{22}$ In particular, they have shown

${ }^{19}$ H.P. Willmott, The Last Century of Sea Power: From Port Arthur to Chanak, 1894-1922 (Bloomington: Indiana UP, 2009), 276; J. Macleod, Reconsidering Gallipoli (Manchester: Manchester UP, 2004), 27-88; Ellison, Perils of Amateur Strategy, 96-134.

${ }^{20}$ Schofield, British Sea Power, 199-200; Fergusson, Watery Maze, 37.

${ }^{21}$ See: J. Ferris, 'Treasury Control, The Ten Year Rule and British Service Policies, 1919-1924' Historical Journal 30/4 (1987), 860-867; D. Edgerton, Warfare State: Britain 1920-1970 (Cambridge: Cambridge UP, 2006), 16-36; C.M. Bell, Churchill and Sea Power (Oxford: Oxford UP, 2013), 88-105.

${ }^{22}$ A.R. Millett, 'Assault from the sea: the development of amphibious warfare between the wars: the American, British and Japanese Experiences', in eds. W. Murray and A.R. Millett 
that while the Admiralty and War Office did limit the allocation of resources to amphibious development, the services nonetheless continued preparing for potential future landings.

\section{Designing the landing}

One key piece of evidence used when reviewing Britain's interwar progress was the Royal Navy's lack of landing craft in commission. Marder remains unchallenged in his assertion that the availability of fewer than a dozen landing craft in 1939 highlighted a deficient approach to amphibious operations. ${ }^{23}$ Reviewing Marder's hypothesis in detail, however, reveals a different picture. After 1918 most of the Royal Navy's 200 ' $\mathrm{X}$ ' lighters were scrapped, with others purchased by shipping firms and foreign governments. ${ }^{24}$ Indeed, a few sold at Gibraltar in 1922 saw action with Spanish and French forces during the 1925 Alhucemas Bay landings. ${ }^{25}$ The 'Beetles', as they were nicknamed, were in any case of limited value in contested amphibious operations, until after beachheads had been secured. ${ }^{26}$ They were extremely noisy, slow to manoeuvre, large and easy for gunners to concentrate their fire upon, and ill-designed for troops and

Military Innovation in the Interwar Period (Cambridge: Cambridge UP, 1996), 59-62;

Harding, 'Amphibious Warfare', 45.

${ }^{23}$ Marder, Dardanelles to Oran, 52.

${ }^{24}$ R.A. Beaumont, Joint Military Operations (London: Greenwood, 1993), 77.

25 J.E. Alvarez, 'Between Gallipoli and D-Day: Alhucemas 1925' Journal of Military History 63/1 (1999), 86.

${ }^{26}$ TNA, Admiralty (ADM) 203/73, Memoranda outlining requirements for new landing craft, 1926; TNA, ADM 1/9331, Report on using the Fleming Lifeboat as a landing craft, 1926. 
equipment to alight quickly onto the beach. ${ }^{27}$ Those attributes were unsurprising given that X-Lighters were constructed as an emergency measure, based on Thames barges, and never intended as true assault craft.

Discussions began in 1921 and a naval committee consequently established in 1924 to develop a new purpose-built, motorised landing craft. ${ }^{28}$ Various options were reviewed, including adapted lifeboats, with the first trials conducted in 1926 . The resultant prototype was given the functional title 'Motor Landing Craft Mk. 1' (MLC). They were self-propelled, bullet-proof, capable of being handled by ocean-going transport vessels, and included features for cutting through barbed-wire barriers. ${ }^{29}$ MLCs could carry and then quickly offload directly onto the beach either 100 fullyarmed troops, or a tank, lorry, or medium artillery piece. What has been understated in existing accounts is that while they were still fairly crude, MLCs were a huge advance from anything previously available. Moreover, the ability to land tanks onto the beach was seen as a means of overcoming barbed wire and machinegun fire - key lessons from Gallipoli. ${ }^{30}$

From the outset the landing craft development committee was never intended to be a precursor to a full construction program, which would require government

${ }^{27}$ TNA, ADM 137/2498, Report by Rear Admiral H. Kelly during the Chanak Crisis, 10 Mar. 1922.

${ }^{28}$ TNA, ADM 116/2086, Memorandum signed by the Director of Training and Staff Division, and Director of Planning, Jan. 1922.

${ }^{29}$ NMM, TRO 401/5, Appendix documents to a lecture by Commander J.C. Leach, Oct. 1930.

${ }^{30}$ Harding, 'Amphibious Warfare', 52. 
approval. Instead the Admiralty launched the program to develop suitable designs that could be put into production when required in wartime. ${ }^{31}$ The 1931 Manual of Combined Operations repeated this point, stating that the latest specialised landing craft designs should only be mass-produced in sufficient time, before future landings, for use during the assault phase. ${ }^{32}$ Practical uses could be found for the prototypes, and indeed were found, with the experience gained fed back into the designs to iron-out technical issues. ${ }^{33}$ In particular, problems encountered when bringing boats to the water's edge precipitated adjustments to the rudder and propulsion system. Given the comparatively short lifespans of such small craft and the financial restrictions facing the armed forces in the 1920s, the strategy adopted was both reasonable and logical. As Gregory Till has argued, Britain's interwar grand strategy did not assume that a standing capability to conduct major amphibious landings was required. ${ }^{34}$ Even in 1939 it would have taken remarkable foresight to have predicted the short-term requirement for thousands of landing craft to conduct largescale assaults around Europe.

In the event, the Royal Navy possessed sufficient specialised craft in 1940 to facilitate the assault on Narvik, for example, including two localised landings against opposition. ${ }^{35}$ When the Landing Craft, Mechanised Mark 1 (LCM) was put into mass-

${ }^{31}$ TNA, ADM 203/73, Landing craft committee proposals, 1924; TNA, ADM 203/61, Paper by Captain E. Unwin relating to 1921 Combined Operations Manual, Oct. 1921.

32 TNA, Ministry of Defence (DEFE) 2/708, Manual of Combined Operations, 1931.

${ }^{33}$ TNA, DEFE 2/781, Lecture by Captain A.U. Willis on Combined Operations, 26 Nov. 1930.

${ }^{34}$ Till, 'Amphibious Warfare and the British', 18.

${ }^{35}$ H. Lunde, Hitler's Pre-Emptive War: The Battle for Norway 1940 (Newbury: Casemate, 2010), 411; Kiszely, Anatomy of a Campaign, 254-270. 
production in 1942 it was the fifth generation in its class, developed through sixteen years' practical experience. ${ }^{36}$ Hundreds of those improved versions were then produced for later operations. The approach taken by the Admiralty had achieved its primary objective - to produce a good-quality design of self-propelled landing craft ready for use in the event of another major conflict.

\section{Keeping par with its international rivals}

The development of specialised landing craft also stands in contrast to arguments that Britain's approach was lacking in comparison to its primary international peers - the USA and Japan. ${ }^{37}$ Some recent accounts such as Craig Symonds' Operation Neptune, have reinforced this notion by only discussing American interwar contributions to the Allies' amphibious preparations. ${ }^{38}$ Even Harding's otherwise excellent account underplays the Royal Navy's relative position over the period as a whole. ${ }^{39}$ The US Navy had dabbled in using adjusted ship's boats in 1913 and experimented with landing craft during the 1920s, but the latter, tentative designs still amounted to little more than updated X-Lighters and were abandoned as unsuitable. ${ }^{40}$ As a result, the US Navy only agreed on its first landing craft design in

\footnotetext{
${ }^{36}$ Not to be confused with the later US Navy 'LCM (2)'.

${ }^{37}$ Fergusson, Watery Maze, 37; Millett, 'Assault from the sea', 59-62.

${ }^{38}$ C.L. Symonds, Operation Neptune: The Allied Invasion of Europe and the D-Day Landings, (Oxford, Oxford UP, 2014), 78-80.

${ }^{39}$ Harding, 'Amphibious Warfare'.

${ }^{40}$ R.G. O'Connor, 'The U.S. Marines in the 20 Century: Amphibious Warfare and Doctrinal Debates' Military Affairs 38/3 (1974), 99.
} 
1939, the Higgins' boat, thirteen years after the Royal Navy obtained its first generation MLC. ${ }^{41}$

Developed by civilian Andrew Higgins, based upon an earlier commercial contract, his craft proved highly versatile and evolved into the mass-produced Landing Craft Vehicle Personnel (LCVP). ${ }^{42}$ Nonetheless by the time the US Navy settled upon Higgins' creation, the Admiralty had already authorised two further specialised classes. To better protect first-wave troops, tenders were issued for an armoured infantry variant, with $£ 10,000$ allocated towards the Landing Craft Assault (LCA) in $1938 .{ }^{43}$ Lessons learned with the MLC contributed towards the LCA proving particularly popular with its crews in operational service and allowed the LCAs to be put into production quickly, with the first commissioned in August $1939 .{ }^{44}$ Similarly, prototype Landing Craft Support (LCS) were developed for close in-shore fire-support. ${ }^{45}$ Purchases of both began before the US Navy issued its initial contract for Higgins'

${ }^{41}$ America also experimented with landing tractors after landing craft. See: G.F. Hoffmann, 'The Marine Corps' First Experience with an Amphibious Tank', 67-71, in eds. G.F. Hoffmann and D.A. Starry, Camp Colt to Desert Storm: The History of U.S. Armored Forces (Lexington: Kentucky UP, 2013).

${ }^{42}$ P. Neushul, 'Andrew Jackson Higgins and the Mass Production of World War II Landing Craft' Louisiana History 39/2 (1998), 138-140.

${ }^{43}$ L.E.H. Maund, Assault from the Sea (London: Methuen, 1949), 11.

${ }^{44}$ J.D. Ladd, Assault from the Sea 1939-1945, (Newton Abbot: David \& Charles, 1976), 35; Brooks, Royal Marines, 253.

${ }^{45}$ Ladd, Assault from the Sea, 170-173. 
boats. ${ }^{46}$ LCAs later became a mainstay of every major European-theatre landing of the war, particularly for mission-critical objectives. ${ }^{47}$ Together, Britain's two main interwar designs accounted for one-third of the first-wave landing craft used during Operation Neptune. ${ }^{48}$

Britain's former ally Japan had been considered a world leader in amphibious tactics since around 1900. However, most of its advances in equipment also only occurred during the $1930 \mathrm{~s} .{ }^{49}$ In particular, the Imperial Japanese Army amphibious assault ship Shinshu Maru, laid-down in 1933, marked the point when Japan went notably beyond its international rivals. ${ }^{50}$ The Shinshu Maru had an internal 'well-deck' where landing craft could be loaded in relative safety, before heading towards the beach. The well-deck feature represented a leap in amphibious capability, enabling an assault force to be despatched towards the beach far quicker, and during less than ideal weather conditions, than was possible with ordinary transport vessels. The first purpose built Anglo-American efforts, Landing Ship Gantries, were not put into production until 1941, with the true equivalent Landing Ship Docks only laid-down in 1942.

Furthermore, the Japanese Army concurrently developed two specialised landing craft, the Daihatsu and Shohatsu, for operation with both the Shinshu Maru and mainstream

\footnotetext{
${ }^{46}$ Symonds, Operation Neptune, 78.

${ }^{47}$ Maund, Assault from the Sea, 41-48.

${ }^{48}$ M. Hastings, Overlord, (London: Pan, 1999), 412.

${ }^{49}$ C.E. Callwell, Military Operations and Maritime Preponderance: Their Relation and Interdependence (London: Blackwood, 1905), 436; E.S. May, Principles and Problems of Imperial Defence (London: Sonnenschein, 1903), 131.

${ }^{50}$ Maund, Assault from the Sea, 5.
} 
warships. ${ }^{51}$ In terms of equipment therefore, Britain went through the 1920 s on a par with Japan and ahead of the USA, with the Royal Navy's amphibious capabilities only starting to slide relative to Japan around 1933.

Britain's global expertise in amphibious operations in the 1920s was not only in equipment. Britain had been developing a Manual for Combined Operations, intended as a best-practice guide for conducting landing operations, since before the First World War. Early versions were quite basic and focused heavily on rules rather than tactics. The 1911 manual, for example, instructed soldiers to remain orderly seated in the landing boats until given permission to disembark by the naval officer in command. ${ }^{52} \mathrm{~A}$ 1913 revision removed most of the worst rules reminiscent of former eras, but unfortunately some of the new guidelines were ignored during the Gallipoli campaign, at great cost. Notably, the emphasis on seizing quickly locations where defenders could fire down on the landing beaches. ${ }^{53}$

The manual was completely overhauled in 1920 with input from officers who served at Gallipoli and who emphasised the campaign's main lessons. In particular, the need for the covering force to push inland immediately, ahead of the main force landing. ${ }^{54}$ Subsequent changes targeted pre-operational preparations, starting with an emphasis on building a rounded intelligence picture of the target area, including aerial

\footnotetext{
${ }^{51}$ Neushul, 'Andrew Jackson Higgins', 137.

52 TNA, WO 33/569, Combined Naval and Military Operations Manual, 1911.

${ }^{53}$ TNA, WO 33/644, Combined Naval and Military Operations Manual, 1913.

${ }^{54}$ TNA, DEFE 2/708, Revisions to the Manual for Combined Operations, 1920, TNA, ADM 116/2086; Manual for Combined Operations, 1925.
} 
photography, and incorporating RAF support. Simple and cheaply constructed training facilities were also proposed to prepare soldiers unused to disembarking from landing craft and the challenges involved in assaulting an enemy-held beach. ${ }^{55}$ Those lessons were based on a mixture of theoretical discussions, training exercises, and reviews of Gallipoli. By 1931, the manual provided a detailed examination of how to conduct modern amphibious operations. This is not to say the manual was perfect. Indeed, training exercises in 1934-35 led to a further overhaul. ${ }^{56}$ Nonetheless, Britain's armed forces entered the 1930s with many of the core principles in place for future success.

In comparison, the US Marine Corps only conducted a single landing exercise 1919-31, when participating in the 1924 US Navy Fleet manoeuvres. ${ }^{57}$ As a result, the US Navy and Marine Corps colleges' theoretical understanding of how to conduct landings was described as outmoded and decidedly basic in $1926 .{ }^{58}$ Indeed, it was only in 1934 that the Corps released its first 'Tentative Manual for Landing Operations', although of comparable quality to Britain's 1931 edition. ${ }^{59}$ America's amphibious capabilities had advanced rapidly during the intervening years while working towards

${ }^{55}$ TNA DEFE 2/708, Manual for Combined Operations, 1931.

${ }^{56}$ Moretz, Thinking Wisely, 317-325.

${ }^{57}$ J. Isely \& P. Crowl, US Marines and Amphibious Warfare (Princeton, Princeton UP, 1951), pp.31-32; O’Connor, 'U.S. Marines in the 20 Century’, 100.

${ }^{58}$ S.P. Rosen, 'New Ways of War: Understanding Military Innovation' International Security 13/1 (1988), 163.

${ }^{59}$ Fergusson, Watery Maze, 37; T.C. Gillespie, S.M. Lesher, P.D. Miner, and B.P. Cyr, 'Composite Warfare and The Amphibians', Marine Corps University paper, Quantico, 23 Mar. 1992, 9. 
the creation of a Fleet Marine Force. ${ }^{60}$ Amphibious training exercises then occurred every year 1934-38, further enhancing the Corps' landing experience. That drive was triggered by growing concern about Japan's foreign policy and the realisation that securing advanced bases in the Pacific through amphibious operations would likely prove critical. ${ }^{61}$ It was only against that background in the mid-1930s that the global balance of amphibious expertise swung towards the two Pacific-focused powers. Britain's armed forces in 1931 were not truly ready for modern amphibious operations. Nonetheless, they were comparatively well prepared when taken in a global perspective, although 'not as badly' might be more appropriate.

\section{The cloud of war in Europe}

The challenge of maintaining overall command and control during a landing operation provides a good illustration to explain why Britain's progress stalled in the 1930s, relative to its international peers. The 1931 Combined Staff College Exercise highlighted that a dedicated headquarters ship was vital for landing operations. ${ }^{62}$ As a result, the Royal Navy conducted a series of studies 1933-37 into amphibious headquarters ships. The study groups concluded that only a purpose-built ship could meet all the requirements, particularly for accommodating radio equipment. ${ }^{63}$ However,

${ }^{60}$ D.J. Ulbrich, 'The Long Lose "Tentative Manual for Defense of Advanced Base" (1936)' Journal of Military History 71/3, (2007), 892.

${ }^{61}$ Rosen, 'New Ways of War', 162.

${ }^{62}$ TNA, ADM 116/3674, Director of Training and Staff Development to Admiralty, 14 Apr. 1932.

${ }^{63}$ Harding, ‘Amphibious Warfare', 55-57. 
detailed plans were prepared for using a Leander-class cruiser instead. The Navy believed sufficient space could be freed for additional communications and plotting tasks by temporarily stripping out some fighting capabilities. Contrary to previous accounts, the Admiralty did continue preparing for the task, but the cost of a purposebuilt vessel simply could not be justified in peacetime. ${ }^{64}$ While their officers reached similar conclusions, Britain chose a make-shift solution, whereas Japan launched the Shinshu Maru, which was fully capable of fulfilling the role.

Nazi Germany's rearmament after 1933 was a significant factor in the Admiralty's decision. With growing concern about defending the British Isles and political unwillingness to markedly increase military expenditure, Britain's armed forces were cautious about financing equipment for niche offensive operations. While by 1935 'German rearmament was reaching the point where its scale could not be cloaked in secrecy and diplomatic obfuscation for much longer', most additional funding initially went to the RAF. ${ }^{65}$ Britain's politicians felt that the public were most concerned about the aerial bombing threat posed by the Luftwaffe, rather than the primary naval threat - Japan. ${ }^{66}$

For the Royal Navy, maintaining overall naval supremacy was expected to allow

${ }^{64}$ TNA, ADM 116/3674, HM Signal School Portsmouth to Admiralty, 13 Dec. 1933; TNA, ADM 116/3674, Commander in Chief Home Fleet to Admiralty, 27 Oct. 1934.

${ }^{65}$ J. Maiolo, Cry Havoc: The Arms Race and the Second World War 1931-1941 (London: John Murray, 2010), 52-54.

${ }^{66}$ R.J. Overy, The Bombing War: Europe 1939-1945 (London: Penguin, 2014), 21-55; Bell, Churchill and Sea Power, 142-143. 
the severance of enemy supply lines, partially mitigating against potential attacks on British territories. If amphibious operations were required to re-secure occupied locations, such as Hong Kong, they were expected to be 'exhausting in the highest degree', requiring significant, sustained investment by the British Empire. ${ }^{67}$ Smaller attacks neutralising Italian bases in the Eastern Mediterranean were a realistic possibility. However, as Italy was unlikely to start a major war by itself, but rather in conjunction with Germany or Japan, Britain would have had bigger things to worry about than the seizure of Rhodes. ${ }^{68}$ The Admiralty therefore prepared amphibious plans and prototype landing craft should they be required, but devoted its resources towards avoiding losing naval superiority, which would almost guarantee defeat. While Stephen Roskill overstated the case, the essence of his argument was accurate; the Royal Navy's primary strategic concern was defence. ${ }^{69}$

In contrast, no realistic direct threats were posed against either Japan or the American mainland during the interwar period. As a result, the two nations were largely free to focus on preparing for offensive or counter-offensive operations in the Pacific islands. Japan had the additional incentive that amphibious capabilities would help bypass potential defensive lines in China. Neither nation had to devote significant

${ }^{67}$ TNA, ADM 116/3125, Rear-Admiral Richmond to Admiralty, 13 Apr. 1925.

${ }^{68}$ S. Ball, The Bitter Sea: The Brutal World War II Fight For the Mediterranean (London: Harper Press, 2010), 3-15; B. Millman, Ill-Made Alliance: Anglo-Turkish Relations 19341940 (Montreal: McGill-Queen's UP, 1998), 11-23; R.J. Overy, The Origins of the Second World War (London: Longman, 1987), 18.

${ }^{69}$ S.W. Roskill, History of the Second World War: The War at Sea. Vol.1, (London: HMSO, 1954), 12. 
resources towards defending against a major land-based strategic bombing war.

Restrictions on investment during the 1930s did play a decisive, if indirect, role in the relative decline of Britain's amphibious capabilities, compared to memories of Gallipoli. ${ }^{70}$ The decline was not, however, as significant as previously stated and the under-investment was entirely logical given the strategic situation Britain actually faced at the time. It was only when necessity beckoned, and fully in line with the Admiralty's long-term policy, that significant orders were placed to assemble a fleet of landing craft.

\section{Preparing to 'hit the beach'}

Better equipment was beneficial, but the personnel intended to assault beaches from landing craft also needed to be organised and trained for the task. A 1924 review of the Royal Marines proposed that their primary function should be as a spearhead 'landing force to preserve order, or to deal promptly with trouble in out of way places'. ${ }^{71}$ The Madden Report, as it was known, argued that major amphibious operation required War Office involvement to provide the main force, but Royal Marines should undertake the skilled task of securing the beachheads. Writing in 1926, Major M. Everett of the Royal Engineers similarly argued that the Royal Marines should be ready 'to land when necessary in peacetime for the preservation of law and order' and to secure advanced operating bases during wartime. ${ }^{72}$ Despite the desire for re-organisation, actual changes were relatively limited. By 1927 specific reference was made to the Royal Marines being, among other things, a 'striking force' for conducing

\footnotetext{
${ }^{70}$ S.W. Roskill, Naval Policy Between the Wars: Vol.1 (London: Walker, 1968), 359.

${ }^{71}$ TNA, ADM 1/8664/134, 'Function and training of Royal Marines', 1924.

${ }^{72}$ M. Everett, 'The Future of the Royal Marines', RUSI Journal, 71/484 (1926), 698.
} 
amphibious operations. However, the manpower for such operations was still drawn on an ad-hoc basis from depots and the Fleet itself, such as the 6th Battalion's deployment to Russia (1919), the 12th Battalion's to Shanghai (1927) and the 1,600 marines assembled during the Abyssinian Crisis (1935). ${ }^{73}$

As the possibility of war increased during the 1930s, the Admiralty did create units dedicated to preparing for specific aspects of wartime amphibious operations. Echoing Major Everett's sentiment, the Royal Navy Staff College reported in 1936 that 'in any war in which the British Empire may be engaged, the seizure of enemy bases will be of great importance in order to ensure the safety of our trade routes. ${ }^{74} \mathrm{Such}$ recommendations fed into the development of the Mobile Naval Base Development Organisation (MNBDO), partly tasked with converting captured ports into forward operating bases. ${ }^{75}$ As with the landing craft committee, the fledgling MNBDO was not established with sufficient resources to actually perform their wartime role, only to plan for such contingencies. While unused against their intended opponent, Japan, the MNBDO's work later filtered into the preparations for landings during the Second World War. Nor was the MNDBO the only case, with the Inter-Service Training and Development Centre (ISTDC) established at Fort Cumberland in 1938. While few in number, the ISTDC's officers had access to the highest levels of the armed forces, and

${ }^{73}$ TNA, ADM 1/8709/102, War Diary of the $12^{\text {th }}$ Royal Marine Battalion, 1927; Beaumont, Joint Military Operations, 72; Roskill, Naval Policy Between the Wars, 142.

${ }^{74}$ TNA, AIR 2/1830, Memorandum entitled 'The Naval Side of Combined Operations and the Necessity for its Development in Peace', 22 Feb. 1936.

${ }^{75}$ Maund, Assault from the Sea, 8. 
two had just returned from observing Japanese landings in China. ${ }^{76}$ Unfortunately, much of their accumulated expertise was lost temporarily in 1939, when the Centre was shut-down at the outbreak of war, although the staff were later reunited in the Combined Operations Headquarters. The short-sighted decision to close the ISTDC provides an insight into Britain's institutional failures in exploiting its interwar efforts.

Crucially, neither unit spent significant time re-fighting the Gallipoli campaign, instead focusing on practical experience gained during training exercises and theoretical work, exploring known practical problems. Maund's account of his work at the ISTDC in this period suggests they spent more time trying to convince Whitehall officials to adopt a German-style petrol can, over the unreliable tins used by British forces, than on reviewing Gallipoli. Indeed, the motivation for their very formation and initial focus was Italy's war against Abyssinia. The British government was concerned about the limited options available for launching offensive operations, had Britain entered the conflict. ${ }^{77}$ 1,600 Royal Marines were assembled at Alexandria, offering amphibious possibilities, but the force merely formed part of the toothless overall attempt at dissuading Mussolini from his course of action. ${ }^{78}$

It is worth contrasting the work done by the Royal Navy with that by the Army. Liddell Hart's key examples that suggested a tunnel-vision style focus on Gallipoli, were land-based exercises conducted primarily by the British Army. ${ }^{79}$ Numerous other

\footnotetext{
${ }^{76}$ Fergusson, Watery Maze, 38-41; Maund, Assault from the Sea, 3-21.

${ }^{77}$ Maund, Assault from the Sea, 5.

${ }^{78}$ Beaumont, Joint Military Operations, 72.

${ }^{79}$ Liddell Hart, Britain Goes to War, 239-255; Liddell Hart, Liddell Hart Memoirs, 281-306.
} 
exercises were held around the British Empire, however, particularly on beaches around Mumbai, following theoretical discussions at the Quetta Staff College. ${ }^{80}$ During one example in 1925, 1,000 servicemen landed using self-propelled craft at Kasid Beach. ${ }^{81}$ Slightly closer to home, a 1928 exercise in Moray Firth involved a battle-squadron, destroyer flotilla, and 1,500 troops, in total roughly 7,000 personnel. ${ }^{82}$ Those cases do not fit with Stephen Roskill's assertion that the 'amphibious exercises carried out in the 1920 s... were on a very small scale. ${ }^{83}$ While not comparable to wartime invasions, they were significant deployments of personnel for the peacetime British armed forces. Moreover, those exercises are almost identical in magnitude to the Fleet Landing Exercises conducted the following decade by the US Marine Corps. While many exercises involved the British Army, they were driven by officers from the Royal Navy. In support of Moretz's discussion of interwar combined operations training, there is little evidence that the RAF played a significant role during interwar amphibious exercises, indeed many reveal no sign of any involvement whatsoever. ${ }^{84}$

Those training operations catalysed numerous secondary studies within the Navy, such as the previously mentioned three years of additional tests and reports

${ }^{80}$ E.g. TNA, ADM 203/84, Memoranda for the combined exercise at Salsette Island, 1924; TNA, ADM 203/74, Memoranda for the combined exercise at Kasid Beach, Dec. 1925. ${ }^{81}$ TNA, ADM 203/74, Report on the combined exercise at Kasid Beach, Dec. 1925; Maund, Assault from the Sea, 2.

${ }^{82}$ TNA, ADM 203/89, Plans and reports for a combined exercise in Moray Firth, 1928.

${ }^{83}$ Roskill, Naval Policy Between the Wars, 539.

${ }^{84}$ Moretz, Thinking Wisely, 265-272. 
exploring tri-service amphibious command ships after a 1931 exercise. ${ }^{85}$ These exercises also fed into the regular updates to the Manual for Combined Operations. The 1922 version for example, changed planning guidance after a training landing revealed that the existing rules were too inflexible for such dynamic operations. ${ }^{86}$ In particular, greater freedom was granted for altering fire-support and follow-up waves in immediate response to events ashore. ${ }^{87}$ The Royal Navy's greater motivation was a direct result of its strategic priorities, rather than any lingering psychological impact from Gallipoli. The Navy was increasingly concerned about the likelihood of a maritime war with Japan and therefore the potential requirement to recapture lost territory, with movement by land restricted or simply impossible. That might not necessitate a full amphibious assault, but rather relatively modest landings supporting a land campaign. In contrast, the Army focused upon unrest in the Middle East and a potential Russian threat to northern India. ${ }^{88}$

Despite the Royal Navy's interwar efforts in developing the manual and specialised equipment, there was a problem in disseminating best practice. Given their relatively niche nature, most naval officers were only afforded a basic knowledge of successful historic amphibious operations, supplemented by copious quantities of

${ }^{85}$ TNA, ADM 116/3674, Reports on Combined Operations HQ Ship, 1931-1937.

${ }^{86}$ TNA, ADM 203/61, Memorandum accompanying the revised 1921 Manual for Combined Operations, 1922.

${ }^{87}$ TNA, ADM 116/2086, Major-General W.H. Anderson to the War Office, 7 Jan. 1920.

${ }^{88}$ A. Clayton, 'Deceptive Might: Imperial Defence and Security 1900-1968', in eds. J.M. Brown and W.R. Louis, The Twentieth Century: Oxford History of the British Empire (Oxford: Oxford UP, 2001), 284. 
patriotic fervour and the spirit of Nelson. ${ }^{89}$ Mainstream interwar training courses, for example, focused on famous classical 'conjunct expeditions' such as Wolfe's heroics at Quebec, with almost no recent examples. ${ }^{90}$ Even Admiral Herbert Richmond barely discussed the First World War in a paper on amphibious warfare, during his time teaching the course. ${ }^{91}$ The few officers that were properly trained and prepared, such as the staff of the ISTDC, were spread thinly across the Service in 1939. Rather than utilising their specialist knowledge to lead or educate landing forces, they were only reunited after needless and costly mistakes had already been made, particularly at Dieppe.

Reconsidering Liddell Hart's account, Gallipoli may well have occupied the thoughts of army officers involved in amphibious exercises. Indeed, a lecture given by an unnamed army officer to the Royal Navy Staff College in 1930 on 'The Army Point of View' shows a heavy influence from the Dardanelles campaign. ${ }^{92}$ Looking at Britain's armed forces as a whole, however, there was no overwhelming, outright objection to the theoretical consideration of amphibious operations. Both the Army and Royal Navy deployed men, materiel, and money to further their understanding of how wartime landings could be conducted effectively. The shadow cast by Gallipoli,

${ }^{89}$ Bell, 'The King's English', 699.

${ }^{90}$ London, UK, King's College London's Liddell Hart Centre for Military Archives (KCLMA), Catalogue ID 1238, Cambridge Course for Naval Officers and notes by L.A. Humphreys, 1922.

${ }^{91}$ H. Richmond, Amphibious Warfare in British History, (Exeter: Paternoster Press, 1941), 28 29.

92 NMM, Arthur Peters papers (PET) 7, Lecture entitled 'The Army Point of View, May 1930. 
therefore, was a relatively faint one, making officers more cautious, through a greater respect of what could go wrong. Brian Bond has also highlighted that army officers at the interwar staff colleges had a general tendency to refight First World War failures, suggesting that, when it was discussed, Gallipoli was treated no differently than other campaigns. ${ }^{93}$

\section{Imperial amphibious necessity}

With a largely maritime empire, deciding to never conduct another sea-to-land operation was simply not an option for the British armed forces, particularly during any likely major conflict. ${ }^{94}$ As Director of Naval Intelligence Captain Gerald Dickens stated during a 1929 lecture; '...however much we may dislike the idea of opposed landings, we shall have to face them. Operations of this nature are inevitable in the amphibious warfare to which this Empire is always committed. ${ }^{, 95}$ Situations where Britain might need to land service personnel to regain control over its territory, whether for colonial policing or due to invasion, were foreseeable for significant tracts of the Empire. The vast British Empire was sparsely policed and defended, with only 130,000 fighting troops in the 1920s British Army and roughly half of them based in India. ${ }^{96}$ Using large

${ }^{93}$ B. Bond, British military policy between the two World Wars (Oxford: Clarendon, 1980), 37. ${ }^{94}$ TNA, Air Ministry (AIR) 10/5533, Manual for Combined Naval, Military and Air Operations, 1925.

${ }^{95}$ KCLMA, Catalogue ID 1114, Imperial Defence College lecture by Captain G. Dickens, 1929.

${ }^{96}$ Hansard, 15 Mar. 1923, vol.161, cc.1829-75; R. Hyam, 'The British Empire in the Edwardian Era', in eds. J. Brown and W.R. Louis, The Twentieth Century: Oxford History of the British Empire, (Oxford: Oxford UP, 1999), 48. 
numbers of personnel to pro-actively secure that territory was not financially nor practically viable, particularly in light of post-war cutbacks. As a result, the only option was a largely re-active approach. Expeditionary forces marshalled around the world by the Royal Navy, fire-fighting against potential and emergent threats. Indeed, with pressure growing on the Army's resources in 1937, Captain John Macnamara MP argued in Parliament that the 'garrisoning of places like (Bermuda or Jamaica) could be done much better by (Royal Marine) landing parties than by expensive infantry battalions.' 97 There were no significant adjustments in favour of a maritime approach, despite the arguments made in the Madden Report and later by Macnamara. Nonetheless, the underlying concept formed a key part of Britain's strategy for policing the Empire.

Against that backdrop, particularly scenarios where regional ports might be lost to insurgents or enemy forces, developing amphibious capabilities does not conclusively prove that the armed forces believed major wartime operations were truly viable. There certainly remained considerable caution about offensive landings against prepared positions after Gallipoli. Reviewing the 1921 revised manual, for example, the Commandant of Camberley Staff College - Major-General Hastings Anderson - stated that he could not think how 'a landing without surprise against a civilised enemy in prepared defences can in future be regarded a feasible operation of war. ${ }^{98}$ The sentiment expressed was not far from the Nelsonian principle, that only a fool would attack a fort from the sea. ${ }^{99}$ In a later report, Anderson qualified his opinion that a

\footnotetext{
${ }^{97}$ Hansard, 17 Feb. 1937, vol.320 c.1280.

${ }^{98}$ TNA, ADM 203/61, Memorandum by Major-General W.H. Anderson, 17 Feb. 1922.

${ }^{99}$ Willmott, Last Century of Sea Power, 278.
} 
landing 'carried out in the face of even moderate opposition... will almost certainly be doomed to failure, - that is, if we do not revolutionize our methods. ${ }^{100}$ While he clearly did not advocate repeating a Gallipoli approach, Anderson's assessment left open a wide range of possibilities.

Within the War Memoranda outlining the Royal Navy's strategy for a conflict with Japan, amphibious operations were discussed as a means of securing victory. The primary strategic focus involved first preventing Japanese offensive operations against the British Empire, by deploying the battle fleet immediately to Singapore, followed by an ever-tightening naval blockade. ${ }^{101}$ To sever Japanese access to the wealth of resources it imported from the Yangtze River basin, a vital step for an attritional approach, Britain required either its forward operating base at Hong Kong, or a similar replacement on the Chinese coast. ${ }^{102}$ As early as 1925 , then Rear-Admiral Richmond identified this as a particularly challenging element of the strategy. Japan was expected to launch a lightning strike down the Chinese coast, seizing key ports. Sufficient time would likely be available before the arrival of the Royal Navy's Battle Fleet for a Japanese assault force to successfully occupy Hong Kong. Major landing operations would therefore be required to re-secure Britain's Eastern Fortress and enable an

100 TNA, ADM 116/2086, Major-General W.H. Anderson to the War Office, 7 Jan. 1920.

${ }^{101}$ C.M. Bell, The Royal Navy: Sea-power and Strategy between the Wars, (Basingstoke: Macmillan, 2000), 60-77.

${ }^{102}$ TNA, ADM 116/3125, War Memoranda issued to Royal Navy Station commanders, Aug. 1924; TNA, ADM 116/3118, War Memoranda issued to Royal Navy Station commanders, Nov. 1932. 
effective interdiction campaign against Japanese convoys in the East China Sea. ${ }^{103}$ Not only were plans discussed, but battalion-strength landing exercises were also conducted at key beaches around Hong Kong, with the added benefit of learning more about the city’s defensive vulnerabilities. ${ }^{104}$

These plans have been tentatively discussed and to some extent dismissed by Bell and Harding and were absent from Andrew Boyd's recent account. ${ }^{105}$ However, the strategic background was more complicated than they acknowledged, as the plans were not based upon a straightforward British Empire versus Japan scenario. Instead the Admiralty believed, fairly accurately as it turned out, that Japanese expansionism would result in conflict with China, and that the Foreign Office could therefore persuade China to support British expeditionary forces. While any landings involved were not necessarily going to be made against opposition, they would have been significant undertakings, conducted 1,400 nautical miles from Singapore. Plans from 1928, reissued in 1933, further proposed that even if Hong Kong survived a Japanese assault, landing operations against prepared defences would have been required to secure vital advanced bases at Xiamen and Sandu'ao Bay. ${ }^{106}$ Indeed, detailed intelligence reports

103 TNA, ADM 116/3125, Rear-Admiral H. Richmond to Admiralty, 13 Apr. 1925.

${ }^{104}$ E.g. Portsmouth, UK, National Museum of the Royal Navy (NMRN), 1994/253/1 Journal of Douglas Poole, 25 June 1924.

${ }^{105}$ C.M. Bell, “"How are we going to make war?” Admiral Sir Herbert Richmond and British Far Eastern War Plans', Journal of Strategic Studies 20/3 (1997), 123-41; A. Boyd, The Royal Navy in Eastern Waters: Linchpin of Victory, (Barnsley: Seaforth, 2017), 4-29; Harding, 'Amphibious Warfare', 47-49.

106 TNA, WO 106/91, Plans for operations in a war against Japan, 25 Oct. 1928. 
were assembled on potential landing sites as far north as Dalian (Port Arthur). ${ }^{107}$ The Admiralty may have hoped never to launch such a risky campaign, but it quietly assigned resources to research, plan, and prepare for the possibility.

A key point to consider at this stage is the variety of scenarios that could involve an amphibious deployment. At the very least, these ranged from full wartime invasions such as Gallipoli - to peacetime interventions that might involve unopposed landings using only a dozen men. ${ }^{108}$ After earlier proposals by Captain Eltham, the 1925 Manual for Combined Operations, for example, tentatively considered defensive landings, coastal support, and riverine operations as additional scenarios. ${ }^{109}$ Likewise, during a 1938 Royal Naval War College lecture Captain Cyril Douglas-Pennant defined three clear types of amphibious operations: raiding, landing, and invasions. ${ }^{110}$ DouglasPennant later demonstrated his expertise commanding the naval forces off Gold Beach in Normandy and then as Commandant of the Combined Staff College. When examining the arguments made at the time, it is therefore crucial to note what types of deployments were being referred to and that not all those categories were exclusively used during wartime.

\footnotetext{
107 TNA, WO 106/5256, Military Intelligence Report on the defences of Dairen, 1926.

108 TNA, DEFE 2/781, Lecture by Captain A.U. Willis on the Organisation of Combined Operations, 26 Nov. 1930.

109 TNA, DEFE 2/708, Manual for Combined Operations, 1925; TNA, ADM 116/2086, Captain E. Eltham to Admiralty, 23 Feb. 1920.

${ }^{110}$ TNA, DEFE 2/781, Lecture by Captain C.E. Douglas-Pennant on Combined Operations, May 1938.
} 


\section{Amphibious raids during the violent peace}

As acknowledged in more recent accounts, amphibious operations were conducted throughout the interwar 'violent peace', albeit not on the scale of wartime invasions. ${ }^{111}$ Nonetheless, the complexity of some peacetime amphibious operations remains understated, even if many were quite modest. ${ }^{112}$ These involved relatively few personnel, although the deployment of HMS Delhi's marines to support Dominican police in 1930 was sufficiently noteworthy to be discussed in the House of Commons. ${ }^{113}$ On a larger scale, the King's African Rifles conducted unopposed landings near Dar es Salaam in the 1930s. ${ }^{114}$ The armed forces of the dominions, Australia, Canada, and New Zealand, also conducted small amphibious landings during the period. ${ }^{115}$ While comparable to simpler wartime raids, their relationship to larger operations is more tenuous. However, not all interwar landings fit that pattern.

Frequent landings were conducted in response to threats against the treaty ports and shipping routes in China during the period. ${ }^{116}$ Compared with a major invasion these operations involved modest numbers of personnel, but still carried a significant

${ }^{111}$ A. Clayton, The British Empire as a Superpower 1919-1939 (Basingstoke, 1986), 212-227; D. Redford and P.D. Grove, The Royal Navy: A History Since 1900, (London: Tauris, 2014), 109-111; Harding, 'Amphibious Warfare', 46; Speller, 'In the Shadow of Gallipoli?'.

${ }^{112}$ Clayton, 'Deceptive Might', 291.

${ }^{113}$ Hansard, 12 Nov. 1930, vol.244, c.1689.

${ }^{114}$ London, UK, Imperial War Museum, PC699, Photographs of King's African Rifles landing near Dar es Salaam.

${ }^{115}$ Hansard, 21 Mar. 1932, vol.263, c.687; Clayton, The British Empire, 290.

116 TNA, ADM 116/2502, China Station correspondence, 1926-1927. 
risk of clashes with sizable and well-armed hostile forces. ${ }^{117}$ In 1925 , for example, one group of 300 pirates (including many ex-soldiers) near Guangzhou possessed four field guns and thirty Thompson submachine guns, in addition to rifles and handguns. ${ }^{118}$ As a result, landing operations against them were only authorised after significant planning had been undertaken, to try avoiding both the loss of men and potential diplomatic incidents that would stoke anti-British protests.

One significant anti-piracy raid in Daya Bay on 31 August 1927 provides a valuable case study. 475 servicemen were landed to destroy a pirate 'nest' and to kill or capture potential suspects. A constant overflight was maintained by aircraft from HMS Hermes and Kai Tak airfield to warn of approaching Revolutionary Army troops and avoid diplomatic incidents, while also intimidating potential adversaries. ${ }^{119}$ When 200 Chinese soldiers were spotted in the afternoon, shore-commander Captain Mackinnon ordered his men onto secondary objectives, increasing the distance between the two forces and ensuring a peaceful re-embarkation. ${ }^{120} \mathrm{Had}$ the efforts to prevent clashes with local troops failed, a 'substantial reserve' was ready to land, with a cruiser and destroyer also available to provide fire-support. ${ }^{121}$ Other examples from the period show similar levels of strength and planning, with some conducted against

\footnotetext{
117 J.D. Ladd, The Royal Marines 1919-1980 (London: HarperCollins, 1980), 22.

118 TNA, ADM 116/2262, Memorandum by Commander Maxwell-Scott, 2 Dec. 1924.

119 TNA, ADM 116/2502, Plans for a raid in Bias Bay, 3 Aug. 1927.

${ }^{120}$ TNA, ADM 116/2502, Report by Captain MacKinnon, 1 Sept. 1927.

${ }^{121}$ TNA, ADM 116/2502, Report by Captain R. Eliot, 4 Sept. 1927.
} 
opposition. ${ }^{122}$ Involving aerial reconnaissance, clear pre-established objectives, prepared naval fire support, and a mobile reserve, these raids against armed opponents were comparable with wartime operations. Moreover, the scale was very close to that of individual beach sectors at major landings during both world wars.

Those interwar deployments are significant as they demonstrate the practical employment of amphibious operations during peacetime against regular and irregular threats. Existing accounts have focused primarily on how amphibious developments related to major conflicts. The interwar peace was far from peaceful, however, and when analysing amphibious developments we should also consider both the 'little wars of Empire' and the conflicts that were narrowly avoided. Indeed, during the 1922 Chanak Crisis a few remaining 'Beetles' were roused out of retirement to ferry troops, weapons, and materiel, with plans prepared for both opposed and unopposed landings. No combat landings actually occurred, but the Dardanelles came remarkably close to hosting a second amphibious campaign. ${ }^{123}$ Appreciating what happened during imperial policing landings is particularly pertinent, as the preparation and operational management often demonstrated a better understanding of amphibious warfare than was displayed during wartime, particularly at Gallipoli and Dieppe.

The landings also provide an important insight into how the British Empire was maintained. That the Royal Navy conducted landings to support the Empire has already

\footnotetext{
${ }^{122}$ E.g. NMRN, 1991/101/67, Journal of Midshipman L.C.S. Sheppard, 1927; TNA, ADM 1/8683/140, Reports by Lieutenant C.M. Faure, June 1925.

123 TNA, ADM 137/2498, Reports by Rear Admiral H. Kelly, 1922-1923.
} 
featured in existing accounts. ${ }^{124}$ However, none go into detail about the mechanism of naval imperial policing. Brief references to service personnel being landed around the world in response to trouble do not highlight the complexity, risks, and planning involved.

\section{Conclusion}

Gallipoli left its mark on all the nations involved in the campaign, particularly among the public. Seven 'official' pilgrimages visited the Dardanelles during the interwar period alone, from Britain and the Dominions, driven by a desire to commemorate the fallen and understand what had occurred. ${ }^{125}$ This extended to servicemen too, but it had little practical impact on Britain's interwar amphibious capabilities and activities. Royal Navy officers in particular saw Gallipoli as a defeated campaign, but not a defeated concept, and many believed that with better preparation and modern equipment, future wartime amphibious operations could be successful. British officers recognised that military technology and tactics had swung in favour of a defending force if it was allowed time to prepare. Acknowledging those new defensive advantages correctly warranted a more cautious attitude towards amphibious operations.

The process was often haphazard, but during the 1920s Britain's armed forces made significant improvements in amphibious understanding and capabilities. As a result, Britain remained a leading global power with expeditionary capabilities, which

\footnotetext{
${ }^{124}$ Clayton, 'Deceptive Might'; R. Bickers, 'Ordering Shanghai: Policing a treaty port, 18541900', in eds. D. Killingray, M. Lincoln, and N. Rigby, Maritime Empires: British Imperial Maritime Trade in the Nineteenth Century (Woodbridge: Boydell \& Brewer, 2004), 174-194. ${ }^{125}$ Lloyd, Battlefield Tourism, 97.
} 
were vastly improved from those available at Gallipoli. The requirement to re-arm after 1933 did restrict investment for specific areas, but Britain's decline relative to its peers during that later period should not be overstated. Key decisions to delay landing craft procurement, for example, were entirely logical against the strategic background and unrelated to earlier failures. Gallipoli's fateful legacy should therefore not be used as a partial explanation for mistakes early in the Second World War. Indeed, the opposite could well be true. As Admiral of the Fleet Lord Roger Keyes mused after the Dieppe Raid:

'The moral of this unfortunate episode is, that it is not sufficient to train and temper an Amphibious Striking Force, unless those who are to command, lacking practical experience, closely study former operations and make use of the experience already gained.' 126

With a largely maritime empire and an undersized standing army, Britain could not avoid using amphibious operations to defend its global interests. For imperial policing this involved relatively small ventures, but many amphibious landings conducted fighting the 'little wars of Empire' were akin to later Commando raids or individual beach sectors during major landings. There is no evidence that Gallipoli had any negative impact upon how officers considered those operations.

The preparations made for potential landings during a war with Japan in particular, highlight that the interwar British armed forces willingly considered launching major strategic campaigns by amphibious means, potentially against opposition. The disaster at the Dardanelles put thoughts of what could go wrong to the

${ }^{126}$ R. Keyes, Amphibious Warfare and Combined Operations, (Cambridge: Cambridge UP, 1943), 86 . 
forefront of many minds, instilling a degree of unease and caution. Even the more pessimistic informed assessments, however, argued that proper preparation and equipment could lead to future success during major amphibious operations. There was no 'Gallipoli Curse' during the period, but many British officers were haunted by Gallipoli’s ghosts. 


\section{Bibliography}

J.E. Alvarez, 'Between Gallipoli and D-Day: Alhucemas 1925', Journal of Military History 63/1 (1999).

S. Ball, The Bitter Sea: The Brutal World War II Fight For the Mediterranean, (London: Harper Press, 2010).

R.A. Beaumont, Joint Military Operations, (London: Greenwood, 1993).

C.M. Bell, Churchill and Sea Power, (Oxford: Oxford UP, 2013).

C.M. Bell, Churchill and the Dardanelles, (Oxford: Oxford UP, 2017).

C.M. Bell, “"How are we going to make war?” Admiral Sir Herbert Richmond and British Far Eastern War Plans', Journal of Strategic Studies 20/3 (1997).

C.M. Bell, 'The King's English and the Security of the Empire: Class, Social Mobility, and Democratization in the British Naval Officer Corps, 1918-1939' Journal of British Studies 48/3 (2009).

C.M. Bell, The Royal Navy: Sea-power and Strategy between the Wars, (Basingstoke: Macmillan, 2000).

R. Bickers, 'Ordering Shanghai: Policing a treaty port, 1854-1900', in eds. D.

Killingray, M. Lincoln, and N. Rigby, Maritime Empires: British Imperial Maritime Trade in the Nineteenth Century (Woodbridge: Boydell \& Brewer, 2004).

B. Bond, British military policy between the two World Wars, (Oxford: Clarendon, 1980).

A. Boyd, The Royal Navy in Eastern Waters: Linchpin of Victory, (Barnsley: Seaforth, 2017).

R. Brooks, The Royal Marines: 1664 to the Present, (London: Constable, 2002).

C.E. Callwell, Military Operations and Maritime Preponderance: Their Relation and Interdependence, (London: Blackwood, 1905).

A. Clayton, 'Deceptive Might: Imperial Defence and Security 1900-1968', in eds. J.M. Brown and W.R. Louis, The Twentieth Century: Oxford History of the British Empire, (Oxford: Oxford UP, 2001).

A. Clayton, The British Empire as a Superpower 1919-1939, (Basingstoke, 1986).

K. Clifford, Amphibious Warfare Development in Britain and America from 1920-1940, (NY: Edgewood, 1983).

D. Edgerton, Warfare State: Britain 1920-1970, (Cambridge: Cambridge UP, 2006).

G. Ellison, The Perils of Amateur Strategy, (London: Longman, 1926).

M. Everett, 'The Future of the Royal Marines', RUSI Journal, 71/484 (1926).

B. Fergusson, The Watery Maze (London: Collins, 1961). 
J. Ferris, 'Treasury Control, The Ten Year Rule and British Service Policies, 19191924', Historical Journal 30/4 (1987).

R. Harding, 'Amphibious Warfare 1930-1939', in ed. R. Harding, The Royal Navy, 1930-2000 Innovation and Defence, (London: Frank Cass, 2005).

M. Hastings, Overlord, (London: Pan, 1999).

G.F. Hoffmann, 'The Marine Corps' First Experience with an Amphibious Tank', in eds. G.F. Hoffmann and D.A. Starry, Camp Colt to Desert Storm: The History of U.S. Armored Forces, (Lexington: Kentucky UP, 2013).

R. Hyam, 'The British Empire in the Edwardian Era', in eds. J. Brown and W.R. Louis, The Twentieth Century: Oxford History of the British Empire, (Oxford: Oxford UP, 1999).

J. Isely and P. Crowl, US Marines and Amphibious Warfare, (Princeton, Princeton UP, 1951).

R. Keyes, Amphibious Warfare and Combined Operations, (Cambridge: Cambridge UP, 1943).

J. Kiszely, Anatomy of a Campaign: The British Fiasco in Norway, 1940, (Cambridge: Cambridge UP, 2017).

J.D. Ladd, Assault from the Sea 1939-1945, (Newton Abbot: David \& Charles, 1976).

J.D. Ladd, The Royal Marines 1919-1980, (London: HarperCollins, 1980).

B. Liddell Hart, The Liddell Hart Memoirs Vol. 1, (London: Cassell, 1965).

B. Liddell Hart, When Britain Goes to War, (London: Faber and Faber, 1935).

D.W. Lloyd, Battlefield Tourism: Pilgrimage and the Commemoration of the Great War in Britain, Australia and Canada 1919-1939, (Oxford: Berg, 1998).

H. Lunde, Hitler's Pre-Emptive War: The Battle for Norway 1940, (Newbury:

Casemate, 2010).

D. MacGregor, 'The Use, Misuse, and Non-Use of History: The Royal Navy and the Operational Lessons of the First World War', Journal of Military History 56/4 (1992).

J. Macleod, Reconsidering Gallipoli (Manchester: Manchester UP, 2004).

J. Maiolo, Cry Havoc: The Arms Race and the Second World War 1931-1941, (London: John Murray, 2010).

A.J. Marder, From the Dardanelles to Oran: Studies of the Royal Navy in War and Peace 1915-1940, (London: Oxford UP, 1974).

A.J. Marder, 'The Influence of History on Sea Power: The Royal Navy and the Lessons of 1914-1918', Pacific Historical Review 41/4, (1972).

L.E.H. Maund, Assault from the Sea, (London: Methuen, 1949). 
E.S. May, Principles and Problems of Imperial Defence, (London: Sonnenschein, 1903).

A.R. Millett, 'Assault from the sea: the development of amphibious warfare between the wars: the American, British and Japanese Experiences', in Military Innovation in the Interwar Period, eds. W. Murray and A.R. Millett (Cambridge: Cambridge UP, 1996).

B. Millman, Ill-Made Alliance: Anglo-Turkish Relations 1934-1940, (Montreal: McGillQueen's UP, 1998).

J. Moretz, Thinking Wisely, Planning Boldly: The Higher Education and Training of Royal Navy Officers, 1919-39, (Solihull, Helion, 2014).

P. Neushul, 'Andrew Jackson Higgins and the Mass Production of World War II Landing Craft', Louisiana History 39/2 (1998).

R.G. O'Connor, 'The U.S. Marines in the 20 Century: Amphibious Warfare and Doctrinal Debates', Military Affairs 38/3 (1974).

R.J. Overy, The Bombing War: Europe 1939-1945, (London: Penguin, 2014).

R.J. Overy, The Origins of the Second World War, (London: Longman, 1987).

D. Redford and P.D. Grove, The Royal Navy: A History Since 1900, (London: Tauris, 2014)

H. Richmond, Amphibious Warfare in British History, (Exeter: Paternoster Press, 1941).

S.P. Rosen, 'New Ways of War: Understanding Military Innovation', International Security 13/1 (1988).

S.W. Roskill, History of the Second World War: The War at Sea. Vol.1, (London: HMSO, 1954).

S.W. Roskill, Naval Policy Between the Wars: Vol.1, (London: Walker, 1968).

B.B. Schofield, British Sea Power, (London: Batsford, 1967).

B.B. Schofield, Operation Neptune, (London: Allan, 1974).

I. Speller, 'In the Shadow of Gallipoli? Amphibious Warfare in the Inter-War Period', in ed. J. Macleod, Gallipoli: Making History, (London: Routledge, 2004).

C.L. Symonds, Operation Neptune: The Allied Invasion of Europe and the D-Day Landings, (Oxford, Oxford UP, 2014).

J. Thompson, The Royal Marines: From Sea Soldiers to a Special Force, (London: Pan, 2001).

G. Till, 'Amphibious Warfare and the British', in T. Farrell, M.J. Grove, G. Till, Amphibious Operations: A Collection of Papers, (Camberley: SCSI, 1997). 
G. Till, 'Hitting the beach: the amphibious experience', in eds. J. Bourne, P. Liddle, and I. Whitehead, The Great World War 1914-45: 1. Lightning Strikes Twice, (London: HarperCollins, 2000).

T. Travers, Gallipoli 1915, (Stroud: History Press, 2009).

D.J. Ulbrich, 'The Long Lose "Tentative Manual for Defense of Advanced Base" (1936)', Journal of Military History 71/3, (2007).

A. Whitehouse, Amphibious Operations, (London: Frederick Muller, 1963).

H.P. Willmott, The Last Century of Sea Power: From Port Arthur to Chanak, 18941922, (Bloomington: Indiana UP, 2009). 